This work is licensed under a Creative Commons Attribution 4.0 International License.

\title{
SVEUČILIŠTE I TEHNOSFERA. KRAJ HUMANISTIKE I MOGUĆNOSTI OBRATA?
}

\section{Sažetak}

U članku se tematizira odnos između sveučilišta kao ideje ozbiljenja znanstveno-tehničkih mogućnosti „napretka“ i „razvitka“ čovjeka na kraju metafizike i onog što proizlazi iz razumijevanja tehnosfere kao vladavine „umjetne inteligencije“ i „umjetnoga života“ analizom četiriju temeljnih pojmova kibernetike: informacije - povratne sprege (feedback) - kontrole - komunikacije. Kritičkom analizom mjerodavnih pristupa tom problemu unutar poststrukturalističkog kruga mišljenja od Jeana-Françoisa Lyotarda do Jacquesa Derridae autor pokazuje da se očuvanje „biti“ onoga što nazivamo humanistikom kao mišljenjem - kazivanjem „na“ egzistencijalnu otvorenost čovjeka može izvesti jedino obratom u samoj „biti“ života izvan redukcije na njegove biogenetske procese. Kada život u svojoj posljednjoj mogućnosti produhovljenja postaje autopoietički sustav koji u tehnologiziranju bitka gubi značajke jednokratnosti i neizvjesnosti, a umjesto toga biva singularnošću i proračunljivošću, znanje „o“ kibernetičkoj razlici čovjeka i svijeta iziskuje radikalnu transformaciju. Ali ne više znanosti i njihova povijesno-epohalnoga mjesta odvijanja svjetske povijesti kao što je to ideja sveučilišta od Humboldta do tzv. Bolonjske reforme. Posljednja transformacija s kojom zapadnjačka metafizika kao onto-teo-kozmo-antropologija gubi vlastitu „bit“ odnosi se na ozbiljenje mogućnosti onog što je 
Friedrich W. Nietzsche namijenio ideji čovjeka - da bude most između „životinje“ i „nadčovjeka“. Članak ima za nakanu ekstenzivnom analizom autorova pojma tehnosfere, kako je to izvedeno u petoknjižju istoimena naziva (Tehnosfera $I-V$ ) pokušati promisliti konzekvencije nove paradigme tehnoznanstvene konstrukcije „umjetnoga života“ za budućnost ideje sveučilišta i moguće nove „misije“ humanistike u tom sklopu.

Ključne riječi: sveučilište, humanistika, tehnosfera, kibernetička razlika, obrat, umjetni život

\section{Uvod}

Da bismo uopće mogli postaviti pitanje iz podnaslova ovog razmatranja - o kraju humanistike i mogućnostima obrata? - nužno je barem okvirno otvoriti problem odnosa između sveučilišta i tehnosfere. Okvir je horizont unutar kojeg se pitanje i problem međusobno uspostavljaju kao način promišljanja samoga okvira. U povijesno-epohalnome hodu zapadnjačke metafizike taj se okvir pojavljuje na stanovit način samorazumljivim i otuda, kako je to Heidegger na svojem putu mišljenja pokazao, bitno nemišljenim. Riječ je o metafizici kao okviru mišljenja i njezinim povijesnim likovima i pojmovnim sklopovima. Već je odatle bjelodano da se ono što pripada u taj okvir mišljenja odnosi na mjesto i položaj čovjeka u njegovoj biti. Ako je razlika između čovjeka i svih drugih bića upravo u tome što mu je uskraćena „nužnost“ esencijalnoga određenja „sudbine“ pa stoga mora voditi svoj život kao egzistencijalni „slučaj“ polazeći od slobode koja nije ni bitak ni biće, posve je jasno da bez razumijevanja odnosa čovjeka i tehničkoga sklopa kojim se u suvremenosti odvija samorazvitak povijesti uopće ne možemo pristupiti bilo kakvom shvaćanju o karakteru i značenju tzv. humanističkih znanosti. Odnos između sveučilišta kao ideje ozbiljenja znanstveno-tehničkih mogućnosti „napretka“ i „razvitka“ čovjeka na kraju metafizike i onog što proizlazi iz razumijevanja tehnosfere kao vladavine „umjetne inteligencije“ i „umjetnoga života“ valja izvesti analizom četiriju temeljnih pojmova kibernetike: informacije - povratne sprege (feedback) - kontrole - komunikacije. Kritičkom analizom mjerodavnih pristupa tom problemu unutar poststrukturalističkoga kruga mišljenja od Jeana-Françoisa Lyotarda do Jacquesa Derridae, pokazat će se da se očuvanje „biti“ onoga što nazivamo humanistikom kao mišljenjem - kazivanjem „na“ egzistencijalnu otvorenost čovjeka može izvesti jedino obratom u samoj „biti“ života izvan redukcije na njegove biogenetske procese. 
Kada život u svojoj posljednjoj mogućnosti produhovljenja postaje autopoietički sustav koji u tehnologiziranju bitka gubi značajke jednokratnosti i neizvjesnosti, a umjesto toga biva singularnošću i proračunljivošću, znanje „o kibernetičkoj razlici čovjeka i svijeta iziskuje radikalnu transformaciju. Ali ne više znanosti i njihova povijesno-epohalnoga mjesta odvijanja svjetske povijesti kao što je to ideja sveučilišta od Humboldta do tzv. Bolonjske reforme. Posljednja transformacija s kojom zapadnjačka metafizika kao onto-teo-kozmo-antropologija gubi vlastitu „bit“ odnosi se na ozbiljenje mogućnosti onog što je Friedrich W. Nietzsche namijenio ideji čovjeka - da bude most između „životinje“ i „nadčovjeka“. To razmatranje ima za nakanu da ekstenzivnom analizom autorova pojma tehnosfere, kako je to izvedeno u petoknjižju istoimena naziva, pokuša promisliti konzekvencije nove paradigme tehnoznanstvene konstrukcije „umjetnoga života“ za budućnost ideje sveučilišta i moguće nove „misije“ humanistike u tom sklopu (Paić, Tehnosfera I-V). No, prije negoli krenemo u takvu analizu čini se neizbježnim odrediti što uopće označava taj „okvir“ kojim se metafizičko mišljenje u svojim epohalnim likovima i mijenama pojavljuje kao razdioba na prirodno-tehničke i društveno-humanističke znanosti. Uspostavljajući osnove za operacionalnu izvedbu vlastita povijesnoga mišljenja u tzv. realnome svijetu rada, Vanja Sutlić u tekstu „Da li je u svijetu rada moguće 'organsko jedinstvo' humano-socijalno-historijskih znanosti?", u dodatku drugome izdanju njegove knjige Praksa rada kao znanstvena povijest (1987) između ostalog kaže:

Okvir-parametar u kojem se još i danas krećemo u oblasti humano-socijalno-historijskih znanosti jest austrijska varijanta Humboldtove reforme univerziteta. Osnovna misao Humboldtove ideje univerziteta jest jedinstvo znanosti, uz pretpostavku da ona znanost koja sve znanosti okuplja i čini njihovu pretpostavku, koja omogućuje posebne znanosti i sintetizira ih, jest filozofija. Druga postavka te koncepcije jest sloboda: sloboda istraživanja, sloboda znanstvenog rada, sloboda iznošenja postignutih rezultata i, konkretnije, sloboda od miješanja izvana ('osamljenost'). Dakle, Humboldt je ideju univerziteta, na osnovu radova Schellinga, Fichtea, Schleiermachera, Steffensa i dr., promislio, formulirao, idejno-politički i organizacijski operacionalizirao. (285-86)

Dva su pojma ovdje sklopljena iz nekoliko samostalnih pojmova: „okvir-parametar“ te „humano-socijalno-historijske znanosti“. Prvi je sklop određen kao ono što mišljenjem kao praksom zbiljski svijet postaje kada to i takvo mišljenje 
djeluje „operacionalno“. Paradoks je, dakle, što Sutlić polazeći od metafizičke redukcije filozofije kao temelja svih posebnih znanosti, pokazuje da je „okvir-parametar" onaj koji proizlazi iz filozofije i iz nje oblikuje ideju sveučilišta kao jedinstva svih znanosti. No, ono što odlikuje upravo onaj drugi sklop koji naziva „humano-socijalno-historijskim znanostima“ (u pluralu) nije ništa drugo negoli sloboda. I to ne bilo kakva, ontički označena sloboda, već sloboda kao uvjet mogućnosti razvijanja same ideje znanstvenosti znanosti. Bez slobode ne postoji mogućnost za bilo kakav razvitak znanosti. To je ključna misao za razumijevanje djelovanja „okvira-parametra" u kojem filozofija još uvijek filozofirajući obasjava naš egzistencijalno pomračeni svijet privida, funkcionalnosti i pragmatike znanja. Paradoks je u tome što tzv. humanistika određuje mogućnost da tzv. prirodno-tehničke znanosti „napreduju“, ali ne same iz sebe, jer su one u svojoj „biti“ tehnologički usmjerene, nego iz težnje čovjeka za samousavršavanjem vlastite slobode, što je temeljna ,ideja“ Humboldtove reforme sveučilišta u modernoj Europi 19. stoljeća koja, eto, još čak i danas, unatoč svim promjenama koje su pogodile svojim posljedicama zapadnjačku civilizaciju, naizgled predstavlja ideal tzv. humanistike u krizi njezine „misije“? Sutlić u nastavku teksta još preciznije tvrdi da je ono „organsko jedinstvo“ svih posebnih znanosti sloboda koja stoji u temelju Hegelove Enciklopedije filozofijskih znanosti (286). No, nije to neka tek puko ljudska sloboda u smislu liberalne ideje individuuma i njegova privatna vlasništva. Posrijedi je sloboda apsoluta kao znanosti ili ideja apsolutne slobode. Ta ontologijski uzdignuta sloboda nije intencionalno usmjerena na stvari i bića, na „nešto“ (quiddittas). Njezina je apsolutnost u tome što sve druge „slobode“ čini uopće mogućim, a time i operacionalno izvedivim pod pretpostavkom da postoji sveza/odnos između biti i pojave njezina bitnog određenja, a to je da su znanosti u njihovu jedinstvu i sloboda kao uvjet mogućnosti istraživanja i autonomije sveučilišta kao mjesta na kojem se istraživanja provode istovjetnost onoga što je u osnovi različito. Razlike između prirode i duha, od Kanta do Schellinga i Hegela, ujedno su i razlike u načinu znanstvenoga pristupa onome što novovjekovna metafizika naziva jedinstvom subjekta i objekta.

Svaki je subjekt ujedno i objekt za nekoga ili nešto i obratno. Taj uzajamni odnos mišljenja pokazuje nam da je znanost u smislu istraživanja vlastita predmetnoga područja uvijek u položaju dvostruke usmjerenosti: prema izvanjskome i unutarnjemu (objektu), ali i prema samoj sebi u smislu promatranja - razmatranja supstancije - subjekta koji znanost čini, ničeanski rečeno, apsolutnom značajkom volje za moć u vrednovanju i tumačenju bitka bića i bitka kao takvog. 
Stoga je pitanje o kraju humanistike i mogućnostima obrata ne samo temeljni problem odnosa između sveučilišta i tehnosfere u suvremenosti. To je istodobno i pitanje - problem o načinu egzistencije „čovjeka“ u okviru djelovanja realizirane metafizike u kibernetici. Ovdje se susrećemo s onime što pripada silaznoj putanji razvitka paradigme mišljenja od početka do njezina kraja. Zacijelo da ideja „čovjeka“ unutar Humboldtove ideje sveučilišta još uvijek ima prizvuk romantične vizije o produhovljenju „prirode“ i usavršavanju ljudskosti s pomoću onih znanosti koje njeguju jedinstvo i sklad jezika u organski shvaćenoj kulturi obrazovanog naroda. Drugim riječima, jezik uz njegovo očuvanje i oblikovanje u modernome svijetu vladavine tehničkoga nihilizma nesumnjivo pripada kontekstu u kojem se ta znamenita ideja reforme sveučilišta pokazala gotovo nedodirljivom (Humboldt 1959). Međutim, ono što u Sutlićevu promišljanju plijeni posebnu pozornost jest postavka da je kibernetika kao metateorija svih posebnih znanosti u suvremeno doba način regulacije procesa kojim se zbiva kapitalizam u totalnome osvajanju svijeta. Kada je na djelu „raspadanje organskog jedinstva znanosti“ (Sutlić, Praksa rada kao znanstvena povijest 286), tada je samo po sebi razumljivo da se ono što nazivam tehnosferom kao sintetičkim jedinstvom logike „umjetne inteligencije“ u tehnogenezi „umjetnoga života“ više ne može održati bez posvemašnjeg procesa „dehumaniziranja“ čovjeka i njegove preobrazbe u subjekta/aktera nastanka posthumanoga stanja. Za taj su sklop obvezujući pojmovi računanja, planiranja i konstrukcije (Paić, Posthumano stanje 65-84). Razumijevanje kibernetike ne odnosi se nipošto samo na ono što su u svojim spisima o tome izveli očevi - utemeljitelji ove znanosti o upravljanju cjelokupnim životnim procesima, poput Norberta Wienera ili Clauda Shannona. Isto tako pojam kibernetike ne iscrpljuje se ni onime što su o tome mislili filozofi poput Gilberta Simondona ili Maxa Bensea. Ne zaboravimo da Heidegger, u dijalogu s Eugenom Finkom u seminaru o Heraklitu, iskazuje unutarnju svezu/odnos između prvotne riječi zapadnjačke metafizike kao što je to logos s informacijom. Time samo pokazuje da je mišljenje koje danas nazivamo kibernetičkim po svojem bitnom određenju uistinu realizacija onog što bijaše $u$ temelju metafizike kao njezin okvir. ${ }^{1}$

\footnotetext{
${ }^{1}$ „Fenomen upravljanja (Steuerung) još je uvijek nejasan u odnosu na Heraklita i na stanje naše krizne sadašnjice. Da je kibernetika ovladala prirodnim znanostima i da vodi naš današnji život u najvećoj mjeri nije nipošto slučajno. Sve je to predodređeno u povijesti nastanka novovjekovne znanosti i tehnike. (...) Nije li i današnja kibernetika sáma ona kojom se upravlja?““ (Heidegger-Fink 26)
} 
Nije riječ tek o apsolutnoj vladavini tzv. tehnoznanosti (technoscience) nad onime što je još preostalo od relikta odavno raspadnute ideje sveučilišta kakvu je imao u vidu Humboldt. Mnogo je čudovišnije što današnji trend uspostave projektivnih svrha tzv. STEM-područja, a očito je da se time potvrđuje Heideggerova postavka da tehnika određuje bit znanosti, a ne obratno, ${ }^{2}$ ukazuje na težnju da se jezik i na njemu zasnovano mišljenje usavršavanja slobode i plemenitih ciljeva odgoja i obrazovanja „lijepe duše“ likvidira jednom zauvijek. Razlog za taj sve učestaliji zahtjev državama u globalnome poretku neoliberalne aksiomatike kapitalizma da smanje financijske izdatke za humanističke znanosti toliko je proširen u svakodnevnom žargonu i svodi se na pragmatičku logiku „koristi i štete“ kao temeljnom aksiomu neoliberalne cost-benefit analize (Paić, Neoliberalism 100-87). Što nam sve to govori? Ponajprije, da se nakon Humboldtove ideje sveučilišta i njezina kraja s usponom američke pragmatičke logike uporabe i koristi znanosti u praktičnome životu društava i država, što je svoj vrhunac dosegla usponom kibernetike 1960-ih godina, nametnulo ono što je trebalo nadomjestiti „raspad organskog jedinstva znanosti“. Ovdje je, naravno, uvijek važno dodati i umjetnosti. Ali zbog same biti ovog procesa vladavine kibernetičkih temeljnih načela u realizaciji bit će i na umjetnost primijenjena ista logika pragmatičke koristi i uporabnosti. Štoviše, nastankom i usponom dizajna kao „znanosti o umjetnome“, još će više umjetnost biti svedena na tehnologiziranje životnoga svijeta i otuda će njezin oslobađajući potencijal stvaralaštva postati načinom djelovanja same tehnogeneze nakon što digitalna simulacija u potpunosti ovlada svjetovima proizvodnje „umjetnoga života“ (A-life). To je, čini se, još nedostatno uočeni problem u brojnim današnjim estetikama i teoriji suvremene umjetnosti.

Što se to nametnulo ključnoj riječi Humboldtove ideje ustrojstva sveučilišta i njegove „misije“ kao što je nesumnjivo „organsko jedinstvo“, a kako pokazuje Sutlić, posrijedi je eminentno Schellingova ideja o dedukciji organskoga iz njegova Sustava transcendentalnog idealizma (1800) te predavanja „O metodi akademijskog studija“ (1803) (Schelling, Ideja univerziteta 123-241)? Ono što je ovdje još zanimljivije jest Sutlićeva postavka kako je Schelling s tom idejom utjecao ne samo na Humboldta u njegovu praktičnome izvođenju sustava i ustrojstva njemačkih sveučilišta, već je i Karl Marx rabio izraz o „organskome jedinstvu“ znanosti. Uz

\footnotetext{
2 „Sve to vodi do postavke Maxa Plancka o bitku: 'Zbiljsko jest ono što se može mjeriti.' Smisao bitka je, dakle, mjerljivost, s kojom se ne uspostavlja tek ono 'koliko', nego naposljetku sâmo uvećavanje i ovladavanje bićem kao predmetom koje služi. To se nalazi već u Galilejevu mišljenju, a ono čak prethodi 'Raspravi o metodi'. Otpočinjemo uviđati ne koliko je tehnika zasnovana na fizici, nego, naprotiv, da fizika proizlazi iz biti tehnike." (Heidegger, Vier Seminare 93)
} 
Schellinga i pod vidnim utjecajem Hegelove dijalektike nastojao je ustrajno na prevladavanju diobe rada. Tek otuda postaje moguće ozbiljenje jednog drugog modela sveučilišta na temelju ideje sinteze znanstvenih disciplina (Sutlić, Praksa rada kao znanstvena povijest 288). Nema sumnje da se to mišljenje kao „okvir-parametar" mora uzeti ozbiljno u razmatranje upravo zbog toga što je kapitalizam u svojoj tehnologičkoj fazi razvitka 1960-ih godina, kada informatika, kibernetika i semiotika kreću u stvaranje novog okvira mišljenja u vidu operacionalnoga programa vizualiziranja događaja, ideju sveučilišta kao „organskoga jedinstva“ ne samo doveo u pitanje, već je sve „organsko“ $i$ „humano“ u bitnome sveo na funkcije i strukture neljudskoga. Uostalom, otvorenost smisla bitka kao otvorenost „carstva slobode“, govoreći Marxovim pojmovima, pretpostavlja nadilaženje okvira „carstva nužnosti“ u kojem se zbiva materijalno zbrinjavanje čovjeka. Kapitalizam i sveučilište u bitnom su proturječju i nepomirljivoj suprotnosti. Razlog leži u tome što kapital počiva na ideji profita, a sveučilište se zasniva na ideji slobode i istine kao procesa istraživanja bez prvog uzroka i posljednje svrhe. U tom smislu ne može izvan „službe“ istini i slobodi istraživanja na kojima počiva znanstvenost znanosti ništa biti posljednje opravdanje ideje sveučilišta: ni transcendentni Bog, niti imanentna država, društvo, narod. Na taj je način odnos sveučilišta i znanosti primjerenih suvremenom svijetu usponom tehnoznanstvene konstrukcije neljudskoga u kapitalizmu postao problematičan.

Zašto? Iz jednostavnog razloga što je umjesto romantične ideje povezivanja znanja i obrazovanja te odgoja „čovjeka“ logika tehnoznanosti (technoscience) postala istraživanje (research). A ono više uopće ne potrebuje čovjeka, a ni drevne institucije antičko-srednjovjekovnoga poučavanja i proučavanja „istine“ kao što su to akademije i sveučilišta. Ako to više nisu posvećena mjesta „organskoga jedinstva“ onog što je, naposljetku, proizišlo iz Schellingove „metode akademijskoga studija“ i njegova „sustava transcendentalnog idealizma“, što onda nadomješta njihovu povijesno-epohalnu prisutnost u svijetu koji više ne možemo očito dohvatiti tradicionalnim metafizičkim pojmovljem? Odgovoru na to pitanje približit ćemo se jedino ukoliko pokušamo odgovoriti na tri prethodno međusobno povezana pitanja:

(1) Što uopće sa sveučilištem u doba tehnosfere?

(2) Kako odrediti smisao onog što tradicionalno nazivamo društveno-humanističkim znanostima nakon uvida o njihovu neizbježnome kraju u doba realizirane kibernetike? 
(3) Ima li „čovjek“ još uvijek mogućnost drukčijeg mišljenja koje mu otvara horizont spasonosnoga izgleda obrata u tehničkome nihilizmu suvremenosti?

\section{Sveučilište kao eksperiment života}

Tijekom povijesnoga razvitka Zapad je bio i ostao mjestom na kojem se sjedinjuju dva temeljna pojma mišljenja i kazivanja - logos i mythos. Ono što Heidegger u spisu Što znači misliti? razdvaja na mišljenje kao računanje (Rechnen) i mišljenje kao kazivanje (Dichten) određuje bit sveučilišta. Posrijedi je „organsko jedinstvo“ ili smislena sveza/odnos između prirodno-tehničkih i društveno-humanističkih znanosti. No, znanost u traganju za istinom „oslobađa“ jedino ukoliko je svijet kao takav još uvijek u sebi razdrt, razdvojen na ideju i pojavu, jednostavno kazano ako je metafizički uspostavljen kao dvojstvo između Jednoga. Nije slučajno, dakle, težnja njemačkoga idealizma, navlastito u Schellinga i Hegela, spram apsoluta ono što ideji sveučilišta podaruje smisao u pokušaju da sama zbilja postane jedinstvom onog što je vjekovno razdvojeno. Uostalom, razdoblje koje obilježava znamenita Humboldtova reforma sveučilišta u Njemačkoj i Europi bilo je istodobno prožeto nastojanjem da se veličina kulturne nacije - države omjeri i nastankom ustanova kao što su bile akademije znanosti i umjetnosti. Sve je to još i danas, čini se, na djelu, unatoč uvelike promijenjenome statusu i znanstvenosti znanosti i onoga što čini bit umjetnosti. Međutim, problem s kojim se suočavamo u promišljanju tog odnosa nije u postojanju ili nepostojanju tzv. organskoga jedinstva „računanja“ i „kazivanja“ te na tim osnovama nastalih znanosti „o“ prirodi i čovjeku. U „Predgovoru“ zbornika Ideja univerziteta to je jasno istaknuo Branko Despot, upozorivši da su sve reforme, pa tako i Humboldtova, u načelu promašene. Zašto je tome tako? Despot izričito tvrdi:

Mrtvo se ne da revitalizirati. Univerzitet se mora utemeljiti u ideji univerziteta ili uopće nije univerzitet. Za one kojima su slike bliže može se kazati: znanosti danas u svom interdisciplinarnom kolu plešu mrtvački ples oko ugasle vatre univerziteta. I da politika reducirana na planove, programe i golu pragmatiku ruku pod ruku s društvom koje mjeru svojih potreba ima u materijalnoj bijedi takovim nazovi-univerzitetom može manipulirati, koliko superiorno toliko i neodgovorno, razumije se samo po sebi. (15) 
Iako se Despot u navedenom tekstu, slično kao i Sutlić, nadovezuje na mišljenje mislioca koji su počevši od novoga vijeka do suvremenosti nastojali promisliti „sudbinu sveučilišta“ probojem granica onoga što predstavlja okvir metafizike uopće, a to su u 19. stoljeću činili upravo Marx i Nietzsche najvjerodostojnije, iako obojica nisu bili profesori na sveučilištu, u oba pristupa susrećemo se s nečim što je svakom takvom misaonome pokušaju zajedničko. Riječ je o tome da sveučilište za razliku od svih unutarsvjetovnih ili izvansvjetovnih fenomena ima tu mogućnost da bude svijet kao sklop bitka, bića i biti čovjeka. Biti čovjekom znači sudjelovati u procesu njegova uzdizanja na rang misaonoga bića kojemu znanje o svijetu određuje smisao egzistencije. Još jednoznačnije: svijet nije ništa izvan ljudske težnje za stvaranjem „novoga svijeta“ na ruševinama „staroga“. Pritom je neporecivo da ideja svijeta u bitnom smislu proizlazi iz ideje sveučilišta shvaćenog kao ozbiljenje ne samo ljudskih mogućnosti stvaranja „novoga“, već i preoblikovanja izvanjskoga svijeta kao prirode u obitavalište svih drugih bića. Sveučilište nije otuda svedivo na logiku istraživanja s kojom suvremene znanosti kao tehnoznanosti (technoscience) žele reducirati „istinu“ na pojam „apsolutne i objektivne istine“, a nije ni ustanova koju je moguće svesti tek na poučavanje, obrazovanje i odgoj, bez obzira na to kako se ta tri pojma međusobno postave u odnos. Nema, pak, nikakve sumnje da je odnos sveučilišta i mišljenja kao kazivanja odnos koji pretpostavlja, i tu je iznova Heidegger obvezujući za samu stvar do koje nam je stalo, razumijevanje onog što čini bit humanizma, humanosti, ideje čovjeka nakon što je „humanizam“ izjednačen s nihilizmom kao biti metafizike (Brief über den Humanismus). Ono što je nemoguće izostaviti u pokušaju promišljanja odnosa sveučilišta i tehnosfere jest taj neprobojni metafizički okvir. Iz njega proizlazi da je sveučilište vladavina ideje nad zbiljom. To unaprijed označava da bez povijesnoga odnosa između relata u relaciji ne možemo izaći van iz začaranoga kruga. Naravno, reći će se, pojam ideje nije mišljen platonistički, što možemo razaznati već u Nietzscheovu spisu O budućnosti naših obrazovnih ustanova, ili s druge strane u Marxovim Teorijama o višku vrijednosti. No, kako god bilo, ideja je uvijek ona koja nosi i uvjetuje mišljenje kao teorijsko-praktično-proizvodni sklop misli s kojima se disponira u povijesnoj igri svjetova. Moguće je čak i da se umjesto odjeka ove drevne metafizičke riječi - pojma s podrijetlom u Platona dospije do sekularizirane inačice teologijskoga mišljenja o smislu i svrsi povijesti, pa da se poput Ortege y Gasseta govori o „misiji sveučilišta“. No, to pretpostavlja nešto naizgled paradoksalno: da, naime, svijet nema smisla sam o sebi, već da mu sveučilište podaruje svrhu i posljednji razlog opstojnosti. Otuda „misija“ ne može biti ništa drugo negoli 
druga riječ za ideju kao uvjet mogućnosti mišljenja u događaju osmišljavanja svijeta s pomoću znanosti i umjetnosti. Ali ono što povezuje znanosti i umjetnosti unutar „misije sveučilišta“ nije ništa znanstveno ni umjetničko. To je „kultura“, način i smisao življenja pojedinca i naroda u doba posvemašnjeg pada u organizirano barbarstvo masovnih društava. Uostalom, sâm Ortega y Gasset o tome kaže:

Otuda proizlazi povijesna važnost koja sveučilištu mora vratiti njegovu središnju zadaću 'prosvjetljenja' čovjeka, mora mu pokazati kulturu njegova vremena u potpunosti, mora mu jasno i precizno otkriti gigantski sadašnji svijet, u koji se njegov život mora uklopiti da bi bio izvoran. (225)

Pošli smo od toga da je s Humboldtovom reformom sveučilišta u 19. stoljeću „utemeljeno“ jedno razdoblje u kojem je između „računanja“ $i$ „kazivanja“ vladalo relativno skladno ravnovjesje. Društveno-humanističke znanosti u svim su zapadnim državama i društvima, pa čak i s iznimkom Amerike, imale zadaću prosvjetljenja i kulturaliziranja čovjeka. Štoviše, ta je zadaća bila ne samo ona koju je sveučilište pronosilo u sukobu sa zahtjevima pragmatičnih potreba kapitalističke modernizacije i vladavine svijetom, već se gotovo ista uloga pripisivala i nastajućim ustanovama akademija. Razlika je samo u tome što su akademije nužno usmjerene na očuvanje tradicije, jer ne obrazuju i ne odgajaju mlade ljude za buduća zanimanja i zvanja, već su društva mahom starijih i životnim iskustvom prožetih odabranih znanstvenika i umjetnika kojima njihovo znanje i stvaralačka inventivnost daju značajke neupitnih autoriteta. Ako je već od samoga početka ideja o „organskome jedinstvu znanosti“, bez koje ipak nije moguće utemeljiti ideju sveučilišta, bila u znaku raspada, iako je ta vrsta dekadencije najveći stupanj užitka u agoniji uopće, bjelodano je da je ono što je uzrokovalo raspad nešto samo po sebi neorgansko. Naše vrijeme ne samo da dokazuje tu postavku. Ono je i samo rezultat temeljne „ontologijske perverzije“ koja se sastoji u tome što je sveučilištu u najrazvijenijim državama i društvima Zapada kao što su SAD, Australija, Kanada, Velika Britanija, Njemačka, Francuska, Italija, unatoč kulturnim razlikama ostavljena formalna „autonomija“ odlučivanja o istraživačkim smjernicama razvitka. Ali su bez obzira na to jesu li sveučilišta privatna, državna ili javna bitna pitanja njegove „misije“ izvan čak i tradicionalne uloge nacije - države. O sveučilištu ne odlučuje ni sloboda istraživanja ni veličajno pravo na autonomiju u odnosu na državu i vjeru, već interes profita transnacionalnih korporacija s njihovim posljednjim razlogom opstoj- 
nosti - „racionalnim izborom“ života na tržištu ekonomskih vrijednosti (Giroux 433-55; Münch).

Što je to uopće - ideja sveučilišta? Možda bismo na to pitanje mogli dati odgovor polazeći od onoga što sveučilište označava „danas“, u „aktualnosti“. Na taj bi način mogli kazati da sveučilište uistinu nema više nikakvu „ideju“ koja ga određuje u svim njegovim preobrazbama iz jednostavnog razloga što je doba $\mathrm{u}$ kojem sveučilišta još postoje i djeluju moguće nazvati krajem metafizike u kibernetičkim sustavima ili, delezovski rečeno, „društvima kontrole“. To znači da je ideja ne samo realizirana nego i da se ono što ona označava u svojoj pojavnosti ne može nikako drukčije izvesti negoli tako što će se opisati „bit“ onoga što je prava značajka ove realizirane metafizike. Riječ je, naravno, o imanentnoj transcendenciji. Kada se sam život shvaća kao imanencija, kao što to iskazuje kasni Gilles Deleuze, posrijedi je upravljanje i regulacija života kao autopoietičkoga sustava polazeći od njegove fluidnosti, postajanja mnoštvom i razlikom, prelaskom iz jednog stanja ravnovjesja između bitka i događaja u drugo stanje. Susrećemo se s logikom trećeg poretka kibernetike za koji vrijedi da iznimka (singularnost) stvara novo pravilo. U slučaju sveučilišta kakvo postoji „danas“, očito je da je ono izgubilo ne samo „ideju“ o prosvjećivanju i kulturaliziranju „čovjeka“ već se dogodilo nešto još čudovišnije. Čovjek više uopće nije cilj onoga što je sveučilište postavljalo kao svoju „misiju“ ili zadaću još od Kanta naovamo. Umjesto toga, logika tehnoznanstvene konstrukcije „umjetnoga života" (A-life) nadilazi granice ljudskoga i neljudskoga. U vrtoglavoj brzini novih znanstvenih dostignuća otvara tako prostor za dosezanje posthumanoga stanja čiste singularnosti. Mnogi su mislioci te kibernetičke razlike, po kojoj informacija kao transformacija stanja određuje sustave kontrole nad životom kao okolinom, poput Gilberta Simondona i Viléma Flussera, jasno uvidjeli da će budući prostor realizacije tehnoznanosti i njihove „misije“ istraživanja "prirode“ $i$ „čovjeka“ biti premješten/razmješten iz zbiljskoga svijeta u virtualne svjetove mislećih strojeva. Iz tog razloga sveučilište će nužno morati biti dekonstruirano i destruirano. U prvome slučaju morat će se iz temelja promijeniti njegova „ideja“ kao i zadaće budućih „humanističkih znanosti“. O tome je na mitopoetsko-utopijski način govorio Jacques Derrida u spisu L’université sans condition / Sveučilište bez uvjeta (2001). U nastavku ću o tome nešto više reći. U drugome, pak, slučaju destrukcija ne znači nikakvo uništenje. Naprotiv, taj pojam valja shvatiti iz naravi Marxove dijalektike, kada se nešto prevladava/ukida (Aufhebung) po 
svojoj formi, a sadržaj se čuva i uzdiže na višu razinu (tollere, conservare, ellevare) (Sutlić, Uvod u povijesno mišljenje: Hegel-Marx 67-68).

Moja je, dakle, postavka, da u doba vladavine tehnosfere laboratoriji istraživačkih centara i instituta nisu više stvar „sveučilišta“. Sada je stvar u tome da tehnoznanosti čovjeka rastemeljuju i svode na homo kybernetesa (biće koje više nije čovjek, već se konstituira istraživanjem i eksperimentiranjem s neljudskim poput primjerice onog što čini australski kibernetički performativni umjetnik Stelarc u svojim transmutacijama mesa/metala/čipa prelazeći granice svega „organskoga"). Istraživanje pripada, dakle, tehnogenezi, odnosno tehnoznanstvenoj konstrukciji života kao autopoietičkoga sustava, dok eksperiment postaje ono što još jedino može preostati od sveučilišta kao „ideje“ u doba potpune realizacije metafizike. To je još samo ono što ne može biti „kultura“, u smislu paideiae, kako su Grci sebe vidjeli u razlici spram drugih naroda i njihovih običaja. Problem s „kulturom“ nastaje već otuda što je posrijedi socijaliziranje i sekulariziranje onog što je bio metafizički okvir njemačke spekulativno-dijalektičke filozofije s vrhuncem u Hegela. Uostalom, to je vidljivo u nadomještanju tzv. Geisteswissenschaften (duhovnih znanosti) s Kulturwissenschaften (kulturalnim znanostima) nakon raspada neokantovske filozofije s počecima u Georga Simmela. Kada kultura zasjedne na mjesto duha kao logosa, nastaje prostor za sva moguća interdisciplinarna preklapanja prirode i njezina drugobitka. Ako nije posrijedi „kultura“, onda može još jedino biti ono što omogućuje „kulturi“ da zaposjeda sva područja već transformiranoga bitka u događaj (quiddittas u quoddittas). Ono što povezuje raspadnute cjeline „organskoga jedinstva“ prirode i duha jest kultura u značenju „svijeta života“. No, život koji se ne može svesti na biologijski zadani okvir egzistencijalno vođene „sudbine“ nije tek posljednja preobrazba fluidnoga i nadomjestivoga „duha kulture“. Umjesto toga život se sada mora razumjeti polazeći od onoga što omogućuje njegovu iskonsku i nadomjestivu „bit“ koja se određuje iz kibernetičkih pojmova informacije - povratne sprege (feedback) - kontrole - komunikacije.

Kada sve to imamo u vidu, posve je jasno zašto su s početkom digitalnoga doba 1990-ih godina gotovo sve tzv. kulturalne znanosti postale ujedno i znanostima o životu. Tri su temeljna načina izvedbe te preobrazbe:

(1) gen + informacija = biokibernetika;

(2) gen + znak = biosemiotika;

(3) gen + kultura + politika=bioetika i biopolitika. 
Tradicionalno-metafizička, kantovski izvedena dioba teorije, prakse i produkcije sada postaje proširena do posljednjih granica „života“ kao uvjeta mogućnosti djelovanja u društvu i onome što pripada ljudskim zajednicama - društvenost i druževnost čovjeka. Ali, da bi do toga uopće moglo doći u umreženim globalnim društvima potrebna je pokretačka moć novoga posredovanja. „Život“ se ne može odvijati nikakvim neposrednim i spontanim tijekom vlastita oživotvorenja bez tehnologijske simulacije kao jedine prave stvarnosti. Na taj se način pokazuje da ključ za razumijevanje tehnosfere kao novog apsoluta koji u sebi sintetizira sve što jest, biva i postaje, nije ništa drugo negoli novo mišljenje. Ono nije ni filozofija niti pripada posebnim znanostima. Mišljenje kao računajuće, planirajuće i konstruktivno jest sintetička i transklasična logika stvaralaštva „umjetnoga života“ (A-life). Stoga sveučilište kao „organsko jedinstvo" znanosti ne može više biti njezina toponomija i topologija. Umjesto toga, sâm eksperiment života iziskuje radikalnu transformaciju, a ne reformu sveučilišta kao uvjeta mogućnosti preobrazbe znanja iz teorijsko-praktičnih u proizvodno-teorijsko-praktične sklopove. Takve danas možemo vidjeti u rezultatima tehnoznanosti (technoscience) poput biokibernetike, neurokognitivnih znanosti, biogenetike, nanotehnologije i biosemiotike. Onaj koji je među prvima uvidio do kakvih dalekosežnih posljedica vodi transformacija znanja i ujedno „ideje sveučilišta“ u razdoblju koje je nazvao izrazito problematičnim iskazom postmoderno stanje (la condition postmoderne) u istoimenoj knjizi iz 1979. godine, bio je francuski filozof Jean-François Lyotard. Pogledajmo kako on opisuje bitnu razliku između spekulativne i pragmatične legitimacije znanja u društvu - državi te kako ustvrđuje distinkciju između dva modela sveučilišta u Europi i svijetu koji tome pripadaju. U knjizi Postmoderno stanje: Izvještaj o znanju čitamo:

U humboldtovskome modelu Sveučilišta svaka znanost zauzima svoje mjesto u sustavu kojim vlada spekulacija. Ulazak jedne znanosti u područje druge može samo izazvati pomutnje, 'šumove', smetnje u sustavu. Suradnja je moguća samo na spekulativnoj razini, u glavama filozofa. Ideja interdisciplinarnosti, nasuprot tome, pripada epohi delegitimiranja i njezinom užurbanome empirizmu. Odnos spram znanja nije odnos ozbiljenja života duha ili emancipacije čovječanstva; to je odnos između korisnika složenih konceptualnih i materijalnih kompleksa koji koriste njihova dostignuća. Oni ne raspolažu nekim metajezikom ni nekom metapričom da 
bi formulirali njegovu svrhu i najbolji način njihove uporabe. Ali raspolažu brain stormingom da bi osnažili njihove izvedbe. (Lyotard 86)

Razlike su, dakle, ne samo u načinu mišljenja, nego i u načinu diseminacije tog mišljenja u praktičnome smislu. Nije potrebno posebno ukazivati na to da je jezik tog drugog modela sveučilišta, znanstvenoga diskursa i retoričke usmjerenosti, posve prilagođen svijetu kojim vladaju modeli transformacije kapitala iz industrijskoga u postindustrijsko društvo, promjene proizvodnje iz sfere fizičkoga rada u sferu kognitivnoga rada za koji je potrebno ekspertno znanje i posebne kompetencije. Naposljetku, Lyotard precizno pokazuje da je posrijedi još jedna, uistinu fundamentalna promjena: empirizam skida s prijestolja vladavinu transcendentalnih filozofija subjektivnosti, a to metaforički rečeno znači da Hume postaje važniji od Kanta za ono o čemu se radi u misaonome okviru nove paradigme znanosti i sveučilišta. Ne iščezava samo ono što je bila svrha prosvjetiteljskoga projekta, a što je imao u vidu i Ortega y Gasset kada je u primarnu „misiju sveučilišta“ postavio zadaću prosvjetljenja čovjeka s pomoću „kulture“ u borbi protiv zloguke sile masovnoga barbarstva mediokriteta (224-25). Nestanak emancipacije čovjeka, međutim, ne znači da novo razumijevanje funkcije i svrhe znanja u postmodernome stanju nema baš nikakvu „ideju sveučilišta“. Naravno da je ima, jer je i usmjerenost empirizmu te sklonost pragmatičkim odlukama moguće samo pod uvjetom vladavine "novog“ koncepta znanja i znanosti uopće. Međutim, ono što je sada uistinu dokaz kraja „velike priče“ (grand récit) ili metajezika metafizike od Platona do Hegela, Marxa i Freuda, kako to formulira Lyotard, jest da umjesto filozofije i humanističkih znanosti čitava operacija nadomještanja i stvaranja novih načela mišljenja - djelovanja dolazi iz okružja američkoga pragmatizma i utilitarizma. To jednostavno znači da se znanje ne određuje iz univerzalnih načela i apriorno, kao što je to bilo mjerodavno za Kanta, nego iz partikularnih načela i aposteriornosti. Trijumf empirizma, preciznije pragmatizma, postaje razvidan u tome što umjesto metajezika emancipacije „čovječanstva“ uloga i zadaća znanosti unutar pluralnog svijeta sveučilišta proizlazi iz glavnog pojma semiotike i strukturalne lingvistike. Posrijedi je performativnost iskaza u sklopu onoga što kasni Wittgenstein naziva „jezičnim igrama“ (Sprachspiele, language games), a to se odnosi ne samo na pragmatiku znanja u informacijskome kapitalizmu „danas“, već i na čitav sklop životnih praksi koje se ubrzano mijenjaju, zastarijevaju, postaju zamjenjivima. Lyotard na kraju 12. poglavlja knjige iskazuje gotovo apokaliptičkim tonom ono 
što neminovno slijedi iz novonastajuće paradigme. Nesumnjivo je da je ona primijenjena u tzv. Bolonjskoj reformi europskih sveučilišta početkom 21. stoljeća.

No, ono što se čini izvjesnim jest da u oba slučaja delegitimiranje i nadmoć izvedbenosti navještaju kraj ere Profesora: on nije mjerodavniji od kompjutorske mreže prijenosa podataka utvrđenog znanja i nije mjerodavniji od interdisciplinarnih timova za izmišljanje novih poteza ili novih igara. (87-88)

Sveučilište bez profesora? U neku ruku da, to je budućnost u znaku vladavine tehnosfere. Zbog njezine plastičnosti i mogućnosti neprestane promjene stanja, zbog toga što označava kibernetički prijenos i pohranjivanje informacija s pomoću neljudskoga „uma“, gubi se autoritet jezika i govora. Na njihovo mjesto dolazi „tercijarna memorija“ mislećeg stroja. Umjetno pamćenje stoga ima primat nad nepouzdanim ljudskim sjećanjem. Ono što Lyotard naviješta, više od desetljeća prije no što je nastupilo doba sveopće razmjenjivosti i umreženosti informacija $\mathrm{u}$ formi slikovnih podataka, jest pragmatiziranje života kao eksperimenta koji određuje moć tehnogeneze. Jezik kojim se služi u opisu fenomena nastanka informacijskoga i kognitivnoga kapitalizma iznimno je vjerodostojan. Isto još više vrijedi kada u spisu Neljudsko: Refleksije o vremenu 1988. godine postavi pitanje o odnosu ljudskoga mišljenja i „čovječnosti“ i onoga što čini bit „umjetne inteligencije“ (A-intelligence), a što pripada interdisciplinarnim znanstvenim pokretima i paradigmama posthumanizma i transhumanizma. Pitanje je imalo retorički prizvuk: „Može li biti mišljenja bez tijela?“ (Lyotard, L'Inhumain). Odgovor do kojeg je dospio nije bilo ništa neočekivano. Da, može, naravno. Ali to više nije „ljudsko“ mišljenje, jer nema u sebi ono što Husserl naziva konceptualnom normom ili intencionalni predmet koji omogućuje da mišljenje kao bit čovjeka istodobno postane njegov najnavlastitiji događaj. Mišljenje-bez-tijela više nije „mišljenje“. Posrijedi je tehnoznanstvena konstrukcija nečega što nadilazi granice ljudskoga. Baš zbog toga što ulazi u područje neljudskoga ukazuje nam kamo smjera logika tehnoznanosti s njihovom težnjom za prodorom u singularnost svemira (Lyotard, L'Inhumain 12-14). Kako razumjeti jezik kojim se nova paradigma znanosti, bez emfaze „organskoga jedinstva“, sada pojavljuje u svijetu kojim vladaju ekspertna znanja, pragmatika i ,jezične igre", koje Lyotard naziva znati - činiti (savoir faire, engl. know how)? Ponajprije, to nije više nikakav metafizički izvor jezika kao kazivanja bez kojeg su tradicionalno postavljene društveno-humanističke znanosti unutar humboldtovski zamišljenoga sveučilišta naprosto nemoguće. Da bi sveučilište u svojoj uzvišenoj 
zadaći usavršavanja „ljudske duše“ i usmjeravanja života iz duha filozofije i umjetnosti uopće doseglo slobodu „osamljivanja“ i distance spram tzv. zbiljskoga života u modernim društvima - državama potrebno je imati ne samo autonomiju odlučivanja o putu istraživanja istine. Štoviše, nužno je imati u vidu i krajnji cilj tog procesa. A njega iskazuje metajezik emancipacije i prosvjećenja „čovjeka“ od svih izvanjskih sila što mu priječe put spram beskonačnosti. Potrebno je, dakle, imati ideju o čovjeku.

\section{2. „Nove humanističke znanosti“?}

Prije no što protumačimo kako istom problemu „ideje sveučilišta“ unutar sklopa društveno-humanističkih znanosti pristupa Derrida u spisu Sveučilište bez uvjeta, u nekoliko ključnih postavki valja izložiti kako se uopće tehnosfera pojavljuje neizbježnim okvirom mišljenja - djelovanja u realiziranoj metafizici. Heidegger je u nizu intervencija još od kraja 1940-ih godina upućivao na problem tehničkoga oblikovanja mišljenja kao kazivanja. Upućivao je, naime, na to da računajuće mišljenje (Rechnen) podjarmljuje svojom logikom konstrukcije i pragmatike sva područja života, pa i samu umjetnost. U predavanju „Podrijetlo umjetnosti i određenje mišljenja“ (1967) stoje ove presudne riječi za buduće razumijevanje i „čovjeka“ $i$,svijeta“.

Stoga važi kružno pravilo kao temeljna crta kibernetički nabačenoga svijeta. Na tome počiva mogućnost samoupravljanja, automacije sustava kretanja. U kibernetički predstavljenome svijetu nestaje razlika između automatskih strojeva i živoga bića. Ona se neutralizira u bezrazlikovnome događaju informacije. (...) U tu jednolikost kibernetičkoga svijeta uvučen je i čovjek. I to čak na odlikovani način. Jer u krugu gledišta kibernetičkoga predstavljanja čovjek ima svoje mjesto u najširem krugu pravila. Shodno novovjekovnoj predstavi o čovjeku on je, naime, subjekt koji se odnosi na svijet kao okružje objekata time što ih obrađuje. Otuda nastala svakovrsna promjena svijeta vraća se natrag na čovjeka. Subjekt objekt odnos jest, kibernetički predstavljen, uzajamni odnos informacije, povratne sprege u odlikovanome krugu pravila, što se sve može opisati naslovom 'čovjek i svijet'. (Heidegger, „Zur Frage nach der Bestimmung der Sache des Denkens“ 6)

Uzmemo li u razmatranje postavku o nestanku razlike „između automat-

skih strojeva i živoga bića" kao početak za promišljanje smisla tehnosfere, morat 
ćemo dospjeti do posve drukčije razlike od one koju je sam Heidegger u Bitku i vremenu iz 1927. godine uspostavio kao „ontologijsku razliku“ između bitka i bića (Sein und Zeit 12-20). Sada se, naime, više ne može govoriti o razlikovanju svjetova sve dok kibernetički sustav upravljanja omogućuje da njegova okolina ima relativnu autonomiju i dok se sam pojam „života“ ne shvaća biologistički. Tehnosfera počiva na drugoj vrsti razlike. Ona proizlazi iz „biti“ kibernetike koja u svoja četiri temeljna pojma (informacija - povratna sprega - kontrola - komunikacija) čini mogućim prevladavanje „prirode“ i konstrukciju „umjetnoga svijeta“. Čin takve konstrukcije jest proizvodno-teorijsko-praktično izvršenje upravo novog načina sinteze između živoga i neživoga, ljudskoga i neljudskoga. Ta je razlika, dakle, kibernetički ustrojena i odnosi se na razliku koja nije više hijerarhijski postavljena kao u evolucijskom nizu. Životinja - čovjek - stroj samo je drugi način povijesnoga razvitka latentne mogućnosti onoga što Grci nazivahu téchne. No, budući da kibernetika nije ni univerzalna znanost ni nova tehnologija upravljanja sustavima i okolinom, već rezultat realizirane metafizike Zapada s njezinim temeljnim pojmom logosa - racionalnosti - računanja, postaje bjelodano da se razlika određuje iz konteksta i situacije, dakle pragmatično. Ono što uopće možemo još razlikovati u odnosu „čovjeka i svijeta“ ili u odnosu između živoga i neživoga gubi razlog ontologijske stabilnosti i postaje razlikom unutar samoga pojma stroja kao razlika racionalnosti i intuicije. Tehnosfera nije ništa drugo negoli sintetičko jedinstvo obojega. O tome svjedoče današnja istraživanja u razvitku „umjetne intuicije“ (A-intuition) u djelovanju kognitivno-emocionalnih „strojeva“ s tendencijom njihova samopokretanja i samoorganizacije (Paić, Tehnosfera I 431-73).

Ono što navlastito pripada „biti“ tehnosfere jest nadilaženje binarnih opreka s kojima se klasična metafizika smatrala neprevladivom granicom ljudskoga mišljenja. Možemo ovdje samo dodati da kibernetička razlika jest upravo ono što je Heidegger najavio na kraju svojeg misaonog i životnoga puta u razlikovanju „čovjeka“ i „svijeta“. No, to nije više u području nečeg što je samo od sebe otposlano i darovano poput bitka, već se otvara kao događaj sintetičkoga djelovanja u stvaranju onog što ontologijski gledano „nije“, ali nije ni Ništa. Otuda se, primjerice, u sintetičkoj biologiji i biogenetici kao dobrom primjeru onog što označavaju u svojem nastojanju tehnoznanosti (technoscience) uvijek radi o kloniranju, a ne o reprodukciji izvornika. Umjesto „bitka“ na djelu je „informacija“ kao univerzalna forma i uzrok sintetiziranja različitih supstancija u stvaranju hibridnih „bića“. 
Kako stoje stvari s odnosom između „čovjeka“ i „svijeta“? I je li sve ovo što smo dosad iznijeli razlog za fundamentalnu dekonstrukciju ne samo pojma društveno-humanističkih znanosti unutar duhovnoga prostora sveučilišta, već i same „ideje čovjeka“? Odmah valja kazati da nije posrijedi ideja o čovjeku, jer bi to pretpostavljalo da je „čovjek“ kao stvar ili objekt tek puki predmet istraživanja suvremenih tehnoznanosti. Doduše, da bi računajuće mišljenje u svojoj konstruktivnosti moglo razvijati i stvarati primjerice nove sintetičke lijekove za smrtonosne bolesti poput raka, nužno je da se „čovjek“ razmatra kao sustav različitih funkcija, kao složena mapa organa od kojih mozak ima najvažniju funkciju, kao što je to očito u procvatu kognitivnih znanosti danas. No, razlika između „ideje čovjeka“ i znanstvenoga pristupa čovjeku kao cjelini njegovih sastavnih dijelova u biologijskom i psihologijskome smislu zacijelo proizlazi otuda što je „ideja čovjeka“ rezultat silazne putanje metafizike i njezine redukcije na antropologije u kibernetičkome razumijevanju odnosa (Wiener). Derrida je u spisu Sveučilište bez uvjeta (2001) postavio za temelj vlastitih refleksija ono stanje koje ,jest“ sa sveučilištem u globaliziranome svijetu i ono što bezuvjetno mora doći iz nadolazećega vremena (l’avenir). U tom smislu nužno je bilo razlikovati „svijet“ i „globus“, „mondijaliziranje“ i „globaliziranje“. Služeći se francuskim izrazom koji upućuje na „monde“ (svijet), Derrida stvara bitnu razliku „svjetova“ (L'université sans condition 6-8). Ono što je svjetovno, što iskazuje svijet kao horizont razumijevanja bitka pripada „čovjeku“ kao njegova mogućnost vođenja egzistencije iz mišljenja i djelovanja slobode; ono što, pak, određuje riječ „globalizacija“ u proširenoj uporabi nije ništa drugo negoli svođenje „svijeta“ na uslužne djelatnosti kapitalističke ekspanzije i podjarmljivanja „čovjeka“ izvanjskim svrhama. Već je u ovome vidljivo kamo smjera njegova misao o sveučilištu bez uvjeta u odnosu na aktualnost globalizirane ekonomije - svijeta, da se poslužim izrazom Immanuela Wallersteina. Ono bezuvjetno, ono što mora doći, iako je upitno je li ta nužnost uistinu istinska mogućnost u ovom svijetu kibernetički vođene svjetske povijesti, istodobno pretpostavlja novo određenje upravo humanističkih znanosti (Derrida, L’université sans condition 13-14).

Što je zadaća tih „novih humanističkih znanosti“? Prema Derridai, one moraju uspostaviti s pomoću dekonstrukcije pojma „humanizma“ $i$ „humanističkoga“ sveučilište koje u kantovskome smislu određuje „kozmopolitstvo i univerzalnost“, ali u novom kontekstu „mondijaliziranja“ s obzirom na dva glavna pojma bez kojih zapadnjački „logocentrizam“ u gradnji ideje sveučilišta nema razloga opstojnosti ni prije ni poslije (L’université sans condition). To su, dakako, 
istina i sloboda. Znanosti „služe“ istini, a sloboda im je u bestemeljnome temelju kao prvi i posljednji razlog njihova smisla. Očito je, nadalje, da Derrida nastoji dekonstruirati poteškoće Kantova programa prosvjetiteljstva nakon iskustva raspada nacije - države u 20. stoljeću i zbog totalitarnih pokreta i ideologija koji su prouzročili 2. svjetski rat i zbog zapadnjačkog imperijalizma i kolonijalizma. Međutim, sve su to ipak političke posljedice nečeg što mora imati dublje, gotovo ontologijsko značenje. Pravi referencijalni okvir takvog bezuvjetnoga sveučilišta nije više prosvjetiteljstvo, već demokracija koja dolazi, jer „istina“ i „sloboda“ ne mogu biti postulati i silom nametnuta načela izvedbe u suvremenom svijetu. Kakvo je mišljenje sada posrijedi koje Derrida uzima za „temelj“ tih „novih humanističkih znanosti“? Osim što je ono nužno „afirmativno i performativno“ (L'université sans condition), ono mora „preuzeti zadaću dekonstrukcije, počevši s vlastitom poviješću i vlastitim aksiomima“ (15). Izostavimo li ovdje, inače zanimljivu razliku spram „,ispovijedanja vjere“, jer Derrida apelira na javni prostor iskaza koji ne niječe pravo vjeri da javno djeluje u demokratskim uvjetima brige za dobrobit političke zajednice, ali brani ideju sekularizma i nepozivanja na autoritet Objave, već na moć mišljenja kao odanosti istini i slobodi, bit će posve jasno da „nove humanističke znanosti“ ne mogu biti više tek nastavak tradicije drugim sredstvima. U tome je i njegova razlika spram zagovornika dijaloga s tradicijom u pitanju „ideje sveučilišta“ kakvu su obrazlagali Hannah Arendt (175-89), Leo Strauss (191-97) i Allan Bloom (325-68) u kontekstu američke republikanske misli. Derrida kaže:

Taj nov pojam humanističkih znanosti, premda ostaje vjeran tradiciji, trebao bi uključiti pravo, teorije prevođenja, pa i ono što se u anglosaksonskoj kulturi, u kojoj se prvotno oblikovala, naziva theory (originalna artikulacija teorije književnosti, filozofije, lingvistike, antropologije, psihoanalize itd.), ali također, dakako, na svim tim mjestima, i dekonstrukcijsku praksu. (...) Povezati na određeni način vjeru u znanje, vjeru u znanju, to znači međusobno povezati momente koje bi se moglo nazvati performativnima s konstantivnim, deskriptivnim i teorijskim momentima. ( Luniversité sans condition 22-23)

Zašto Derrida toliko, uostalom kao i Lyotard, inzistira na performativnome karakteru jezika i kazivanja? Odgovor se nudi već sam od sebe. Zbog toga što je izvedbenost jezika svojevrstan čin ili događaj promjene stanja bitka. Kao što je u izvedbenoj umjetnosti tijelo ono koje „govori“ gestualno i simbolički, tako se i u slučaju performativnosti znanosti pojavljuje događaj s kojim više ništa 
nije „isto“. Razlika i događaj, dakle, proizvode situaciju koju u humanističkim znanostima mora izazvati unošenje novih pojmova u jezik tradicije. Nije li, uostalom, sam Derrida u kanonskome djelu poststrukturalizma O gramatologiji (1967) unio upravo performativnost i događaj u razmatranje pisanja kao traga razlike unutar razlučivanja u tekstu (differánce), tako što je pokazao kako se kibernetičkim pojmovima rastemeljuje metafizička struktura glasa u njegovoj prisutnosti. Poslušajmo što Derrida kaže na jednom mjestu svojeg glavnog filozofijskoga djela:

$\mathrm{U}$ istom značenju biolog danas govori o pismu i pro-gramu kada govori o najelementarnijim procesima informacije u živoj stanici. Naposljetku, postoje li ili ne bitne granice, svekoliko područje koje prekriva kibernetički p r o g r a m postat će poljem pisma. Za pretpostaviti je da teorija kibernetike može u sebi obuhvaćati sve metafizičke pojmove - sve do onih duše, života, vrijednosti, izbora, sjećanja - koji su se donedavno rabili kao suprotstavljanje stroja čovjeku, ona će, dok se njezina povijesno-metafizička pripadnost također objelodani, morati sačuvati pojam pisma, utiska, grama ili grafema. (De la grammatologie 19)

Kako se iz programa i pisma za koji već danas misleći strojevi sami proizvode događaj prevođenja simbola u sliku, signala u pismo, otvara mogućnost humanističkim znanostima da ostanu na tragu vjernosti tradiciji uz nužnu preinaku ili dekonstrukciju njezinih „zabluda“, „arhaizama“, „nesuvremenosti“? Što činiti uopće s tzv. kanonom književnosti od antike i srednjega vijeka preko renesanse i baroka do avangarde? Zar je to tek puki prijenos ,ideje čovjeka“ kroz povijesne epohe kao virtualna navigacija prošlošću koja nas, eto, toliko bezuvjetno obvezuje? U analizi procesa kojim kapitalizam u globaliziranome „svijetu“ osvaja nova tržišta, iziskuje promjenu u samoj strukturi rada, teži beskonačnome razvitku informacijskih tehnologija koje ujedno dovode do „kraja rada“ u materijalnome smislu i proširenju rada na sva područja slobodnoga vremena, Derrida dolazi do zaključka da je zahtjev za „sveučilištem bez uvjeta“ ujedno i zahtjev za sveučilištem na kojem „nove humanističke znanosti“ ispunjavaju posve drugu svrhu od klasičnog obrazovanja studenata za „svijet rada“ u globaliziranoj ekonomiji.

Uglavnom, što Derrida baveći se antropologijskim analizama „kraja rada“ otvara kao problem za nadolazeće doba "novih humanističkih znanosti“? Ako bismo htjeli biti cinični rekli bismo jednostavno ovo: uistinu „ništa novo“. Pre- 
poručuje, pak, na hermetičan i dekonstrukcijski način upravo ono što stoji u temelju tzv. Bolonjske reforme visokog obrazovanja u Europi krajem 20. i početkom 21. stoljeća. A to je višak interdisciplinarnosti, prelazak iz jednog u drugo područje znanosti, pokušaj da se „humanističko“ polje povijesno artikulira kao uvjet mogućnosti bezuvjetne volje za „istinom“ i „slobodom“. U sedam točaka ili programatskih sklopova Derrida varira ideju dekonstrukcije humanističkih znanosti polazeći od problematiziranja kraja suverenosti nacije - države, kraja rada, kraja čovjeka u metafizičkome smislu (L’université sans condition). No, ono što je ovdje najznačajnije jest da se znanje više ne razmatra kao prijenos informacija „o“ predmetu, već kao performativni događaj tumačenja njegove složene strukture i biti. Pitanje o mogućnostima „novih humanističkih znanosti“ naposljetku jest pitanje o mogućnostima „ideje čovjeka“ u doba kada sve antropologije u svojem naizgled trijumfu nad društvom, politikom, pravom i moralom nastoje onome „ljudskome-odveć-ljudskome“, govoreći Nietzscheovim slikama - pojmovima, podariti integrativnu i sintetičku platformu za uvid u njegovu nadolazeću „sudbinu“. Za tako nešto nije više dostatno ostati unutar horizonta Kanta i njegovih refleksija o uvjetnim i bezuvjetnim načelima postojanja „ideje sveučilišta“.

\section{Kibernetika i antropologija}

U raspravi „Prebolijevanje metafizike“ Heidegger kaže:

Filozofija u razdoblju dovršene metafizike jest antropologija. /.../ Hoće li se ona ili neće doista još nazivati 'filozofijskom' antropologijom, posve je svejedno. U međuvremenu je filozofija postala antropologijom i na tom putu dospjela do prinosa potomaka metafizike, tj. fizike u najširem smislu, koja uključuje fiziku života i čovjeka, biologiju i psihologiju. Postavši antropologijom, filozofija sama zapada u metafiziku. („Überwindung der Metaphysik“ 82-83)

Vidimo, dakle, da savez kibernetike i antropologije označava uistinu nešto „novo“. Ali to nije nikakav razlog za stvaranje „novih humanističkih znanosti“ kakve postulira utopijski Derrida za „sveučilište bez uvjeta“ ili „sveučilište koje dolazi“. Naprotiv, kibernetička antropologija koja odgovara tehnosferi ne može biti drugo nego „transklasična“ ili „transdisciplinarna“ znanost o čovjeku i njegovoj umjetnoj okolini (Rieger 2003). Tehničko ozbiljenje čovjeka jest ozbiljenje metafizičkih mogućnosti od ranoga grčkoga mišljenja do onoga što Heidegger 
u navedenom tekstu naziva fizikom života u najširem smislu riječi. Vidjeli smo, uostalom, kako to tumači i izvodi u seminaru s Finkom o Heraklitu. Osim biologije i psihologije kao „fizike života“, koja određuje što jest uopće smisao antropologije, postoje još i područja društva, politike i kulture. Čini se da su to još preostala područja reguliranja onog što danas suvremene znanosti o interakciji ekonomije, ekologije i sociologije nazivaju u skladu s neoliberalnim shvaćanjem globalizacije - upravljanjem ljudskim resursima. Kako je moguće u tom sklopu snaga i moći, u vremenu vladavine tehnosfere kao fluidnog i metastabilnoga apsoluta koji se sam stvara i razara, obnavlja, mijenja, postaje drukčijim, iz mnoštva prelazi u Jedno i iz Jednoga u Sve, još uvijek ne samo govoriti o „humanističkim znanostima“, već i o čovjeku bez izravnog odnosa spram njegove „nove“ prirode ili biti. Ako to više nije egzistencijalno ustrojstvo slobode za ono neizvjesno i nadolazeće, nego ono ponovljivo i konstruktivno kao računajuće i planski usmjereno, onda je samo po sebi jasno da različiti „krajevi čovjeka“, o kojem su mislili i kazivali i Foucault i Derrida, i Flusser i posthumanisti, ne znači ništa drugo negoli pokušaj obrata iz situacije u kojoj razlika između „čovjeka“ $i$ „svijeta“ biva određena odnosom kibernetike i antropologije. Što, dakle, preostaje od čovjeka i što preostaje čovjeku kao biću koje se određuje pojmom animal rationale? Kada „stvar" mišljenja postaje mišljenje kao stvar u formi autonomnoga objekta koji računa, planira i konstruira situacije, tada čovjek nužno prelazi svoje biološke granice i zadanosti. Mišljenje koje mu podaruje smisao ljudske egzistencije nije time iščezlo u nepovrat. Ono se samo rekombinira i rekonstruira u različitim, otvorenim formama života, koje višu nisu jednoznačne. Stoga je posljednja mogućnost stvaralačke imaginacije u spoju umjetnosti i tehnoznanosti i to estetskim samooblikovanjem čovjeka kao homo kybernetesa koji više ne upravlja svijetom kao okolinom, jer je i sam dio te iste okoline. Njegova je jedino preostala zadaća i odgovornost da u otvorenosti mogućnosti sačuva smisao ljudske egzistencije u susretu s tehnosferom kao izazovom i izgledom, a ne zlokobnim aparatom rastjelovljenja. Kako još veličajno i s puno patosa odjekuju riječi Lea Straussa o „humanističkome obrazovanju“ u odnosu na ono što je već toliko daleko odmaklo od razdoblja kada je vjera u jezik i smisao „kulture" bila istodobno neupitna vjera u klasično razumijevanje svekolike metafizike s njezinim idealom samousavršavanja čovjeka s pomoću filozofije i umjetnosti:

Humanističko obrazovanje, koje se sastoji od trajnog općenja s najvećim umovima, jest vježbanje najvišeg oblika skromnosti, da ne kažemo i poniznosti. To je vježbanje odvažnosti: ono što od nas zahtijeva potpun 
prekid s bukom i metežom, s nepromišljenošću, s niskošću sajma taštine intelektualaca, ali i njihovih neprijatelja. Zahtijeva odvažnost sadržanu u odluci da se prihvaćena gledišta smatra tek mišljenjima ili da se prosječna mišljenja smatra ekstremnim mišljenjima za koja je jednako vjerojatno da su pogrešna kao i za najneobičnija ili najmanje popularna mišljenja. Humanističko obrazovanje je oslobađanje od vulgarnosti. Grci su imali prelijepu riječ za 'vulgarnost'; nazivali su je apeirokalía, manjak iskustva o lijepome. Humanističko obrazovanje pruža nam iskustvo o lijepome. (Strauss 197)

\section{Zaključak}

Estetsko i performativno polje djelovanja tehnosfere nadmoćno je čitavoj metafizičkoj povijesti vladavine strojeva. Zašto je tome tako? Razlog leži u tome što „Veliki Treći“ nije više moguće nazivati mašinom ili strojem. Ovdje je riječ o transformacijama i mutacijama „same stvari mišljenja“ (to autó, das Ding selbst) do stupnja samosvjesnoga stvora/stvari koji drukčije misli. Ali ne više u razlikovanju onoga što je Heidegger uspostavio kao razlikovanje analognoga i digitalnoga svijeta kroz mišljenja kao kazivanje (Dichten) i mišljenje kao računanje (Rechnen) (Heidegger, „Zur Frage nach der Bestimmung“ 620-33). Ako se, dakle, nova razlika uspostavlja tako što sada „konstrukcija svijeta“ pretpostavlja for$\mathrm{mu}$,umjetne inteligencije“ (A-intelligence), onda je samorazumljivo da se „stvar mišljenja“ preobražava u problem „misleće stvari“ ili autonomnoga objekta posve drukčijeg načina egzistencije od ljudskoga-odveć-ljudskoga. Ideja autonomnoga objekta očigledno obuhvaća tri međusobno povezane tehnoznanstvene „discipline“:

(1) kompjutorsku simulaciju i tehnogenetsku konstrukciju

(2) robotiku, nanotehnologiju i genetsko inženjerstvo

(3) vizualnu semiotiku i pragmatiku ,jezičnih igara“ (Sprachspiele).

Sada se obrat sastoji u tome što se pojam samozakonodavne volje premješta $\mathrm{u}$ „umjetni um“ (A-intelligence). Jasno je da njega više ne predstavlja spekulativno-dijalektička uporaba u filozofiji, već se sve izvodi iz pojma kibernetički ustrojenoga mozga kao sjedišta svih procesa uklopljenosti/ugradnje (embeddment) novih sklopova (Haugeland 105-43). „Mozak“ nije stoga tek puki organ mišljenja. Njegova je funkcija operativna: da konstruira nove tehničke svjetove, 
a ne da opisuje postojeći u njegovim proturječjima i antinomijama. Obrana i dostojanstvo „ideje čovjeka“ s pomoću humanističkoga obrazovanja očigledno više nije ništa samorazumljivo. Već ovaj naraštaj studenata uči i obrazuje se tako što se „umrežava“, interaktivno povezujući informacije u vizualnome kôdu s onime što, deridijanski, možemo nazvati „gramatiziranjem svijesti“. Nije tek prošlo doba Profesora, kako je to apokaliptički jasno i krajnje odmjereno samoj stvari koja nam je u obzorju razmatranja postavio Lyotard u svojem temeljnome djelu Postmoderno stanje (1979). Prošlo je i doba arhitekata, jer gradnja postaje ugradnja i dizajniranje na temelju već postojećih programa izvedbe u inženjerskome i estetskome smislu. Sve što se još može reći o humanistici općenito jest da je posrijedi upravo ono što se mora performativno „uključiti“ u mreže događaja koje označavaju vladavinu autonomnih objekata koji misle tako što računaju, planiraju i konstruiraju stanja objekata u transformaciji. Već sutra prirodni će jezici biti muzealizirane tvorbe zastarjelih kultura i zastarjeloga „čovjeka“, a prevođenje tekstova koji pripadaju veličajnoj prošlosti od antike do naših dana obavljat će Google-translator ili već drugi možda moćniji i učinkovitiji sustavi preradbe i pohrane informacija. Škola i akademije, na koje su oduvijek računale različite filozofijske orijentacije, sve gotovo suglasne da je znanje prijenos umnih tvorbi ne samo zalog pamćenja kulturne tradicije, već i zavjet očuvanja same povijesti kao tijeka smislenoga zbivanja na kojemu je počivala metafizika, neće više biti u krizi. Kao što znanosti umjesto sveučilišta pronalaze svoj pravi „dom“ u ustanovama znanstvenih instituta za fundamentalna i primijenjena istraživanja, tako i sveučilište postaje mjestom društveno-kulturalne interakcije između korisnika informacijskih sustava, a izvorna se zadaća i sveučilišta i humanističkih znanosti svodi na muzealiziranje i historiziranje događaja.

Što još, dakle, preostaje od „čovjeka“ i njegovih iluzija o vladavini onog što je Leo Strauss na uistinu upečatljiv način nazvao ,iskustvom lijepoga“ (197)? Ne mnogo, doista ne mnogo. Možda samo u tom savršenom svijetu satkanom od kozmičko-tehničkih struna apsolutne vizualizacije događaja kao posljednjeg dokaza vladavine „svjetla uma“ nad silama tame još preostaje mogućnost spasonosnoga obrata u tome da je singularnost čovjeka u njegovu mišljenju izvan realizirane metafizike. Mišljenje je to koje ne luta labirintom znakova bez značenja i ne zanosi se trijumfom pragmatičke logike stvari koja nam kaže da je sve što je korisno ujedno i svrsishodno. A kao što znamo pojmovi uporabe i koristi pripadaju estetiziranome svijetu posthumanoga stanja. Preostaje sloboda u mišljenju koje još uvijek ima mogućnost da nasuprot sveopćoj tehnologizaciji 
i vizualizaciji života kaže NE takvom svijetu, koliko god se to činilo uzaludnim naporom dosezanja Mjeseca. To NE afirmacija je života kao duhovne pustolovine bez metafizičkih uzroka i svrhe putovanja na kojem je dostojanstvo čovjeka u tome što ne zna kamo će ga taj put odnijeti i hoće li to biti njegov kraj ili novi početak. Mišljenje bez odjelovljivanja i pragmatičke logike bitka pravo je dostojanstvo i posljednja zadaća čovjeka u doba tehnosfere.

\section{Literatura}

Arendt, Hannah. „Kriza u obrazovanju.“ Preveo Snježan Hasnaš, Europski glasnik, br. 14, 2009, str. 175-89.

Bloom, Allan. „Student i sveučilište." Preveo Snježan Hasnaš, Europski glasnik, br. 14, 2009, str. 325-68.

Deleuze, Gilles. Pure Immanence: A Life. Zone Books, 2005.

Derrida, Jacques. De la grammatologie. Édition de Minuit, 1967.

---. L’université sans condition. Galilée, 2001.

Despot, Branko. „Predgovor: Univerzitet kao znanstvena ustanova ili čovjek kao znanstveno robovanje." Ideja univerziteta, Globus, 1991, str. 7-17.

Giroux, Henri A. „Korporativni rat protiv visokog obrazovanja.“ Preveo Snježan Hasnaš, Europski glasnik, br. 14, 2009, str. 435-55.

Haugeland, John. „Der verkörperte und eingebettete Geist.“ Philosophie und Verkörperung: Grundlagentexte zu einer aktuellen Debatte, uredili Fingerhut Joerg, Hufendiek Rebekka i Wild Markus, Suhrkamp, 2013, str. 105-43.

Heidegger, Martin und Eugen Fink. Heraklit: Seminar Wintersemester 1966-1967. V. Klostermann, 1970.

Heidegger, Martin. Sein und Zeit [1927]. M. Niemeyer, 1976.

Heidegger, Martin. Vier Seminare. V. Klostermann, 1977.

---. „Die Herkunft der Kunst und die Bestimmung des Denkens“ (1967). Distanz und Nähe: Reflexion und Analysen zur Kunst und Gegenwart, uredili Petra Jaeger i Rudolf Lüthe, Königshausen \& Neumann, 1983, str. 16.

---. „Zur Frage nach der Bestimmung der Sache des Denkens“ (1965). Reden und andere Zeugnisse eines Lebensweges (1910-1976), GA, sv. 16, V. Klostermann, 2000, str. 620-33.

---. Was heißt Denken? GA, sv. 8, V. Klostermann, 2002.

---. „Überwindung der Metaphysik.“ Vorträge und Aufsätze, Clett-Kotta, 2009, str. 82-83.

---. Brief über den Humanismus. V. Klostermann, 2010.

Humboldt, Wilhelm von. Bildung und Sprache. F. Schöningh, 1959.

Lyotard, Jean-François. La condition postmoderne. Minuit, 1979.

---. L'Inhumain: Causeries sur le temps. Galilée, 1988. 
Münch, Richard. Globale Eliten, lokale Autoritäten: Bildung und Wissenschaft unter dem Regime von PISA, McKInsey \& Co. Suhrkamp, 2009.

Ortega y Gasset, José. „Misija sveučilišta.“ Preveli Nikola Pezić i Tanja Tarbuk, Europski glasnik, br. 14, 2009, str. 199-232 .

Paić, Žarko. Posthumano stanje: Kraj čovjeka i mogućnosti druge povijesti. Litteris, 2011.

---. Tehnosfera I-V. Sandorf i Mizantrop, 2018-2019.

---. Neoliberalism, Oligarchy and Politics of the Event: At the Edge of Chaos. Cambridge Scholars Publishing, 2020, str. 100-87.

Rieger, Stefan. Kybernetische Anthropologie: Eine Geschichte der Virtualität. Suhrkamp, 2003.

Schelling, Friedrich W. J. „O metodi akademijskoga studija.“ Preveo Branimir Despot, Ideja univerziteta, Globus, 1991, str. 123-241.

Strauss, Leo. „Što je humanističko obrazovanje?“ Preveo Goran Vujasinović, Europski glasnik, br. 14, 2009, str. 191-97.

Sutlić, Vanja. Praksa rada kao znanstvena povijest: Povijesno mišljenje kao kritika kriptofilozofijskog ustrojstva Marxove misli. Globus, 1987.

---. Uvod u povijesno mišljenje: Hegel-Marx. Demetra, 1994.

Wiener, Norbert. The Human Use of Human Beings: Cybernetics and Society. Da Capo Press, 1988. 


\title{
THE UNIVERSITY AND THE TECHNOSPHERE. THE END OF THE HUMANITIES AND THE POSSIBILITIES OF REVERSAL?
}

\begin{abstract}
Žarko PAIĆ

University of Zagreb

Faculty of Textile Technology

Baruna Filipovića 28 a

HR - 10000 Zagreb

zarko.paic@ttf.unizg.hr
\end{abstract}

The article discusses the relationship between universities as the idea of realizing scientific and technical possibilities of "progress" and "development" of man at the end of metaphysics and that which arises from understanding the technosphere as the rule of "artificial intelligence" and "artificial life" through the analysis of four basic concepts of cybernetics: information-feedback-controls-communications. By critically analyzing relevant approaches to this problem within the poststructuralist circle of thought from Jean-François Lyotard to Jacques Derrida, the author shows that preserving the "essence" of what we call the humanities as a thought-saying "on" the existential openness of man can only be done by its reduction to biogenetic processes. When life, in its last possibility of spiritualization, becomes an autopoietic system that loses the features of uniqueness and uncertainty in the technologization of Being and instead becomes singularity and calculability, the knowledge of the "cybernetic difference between man and the world" requires a radical transformation. But not the transformation of science and its historical and epochal place of world history as is the idea of the university from Humboldt to the so-called Bologna reforms. The last transformation with which the Western metaphysics as an onto-theo-cosmo-anthropology loses its own "essence" concerns the realization of the possibility of what Friedrich Nietzsche intended for the idea of man - to be a bridge between an "animal" and "superman." The article intends to reconsider the consequences of the new paradigm of technological structure of "artificial life" for the future of the idea of the university and possibly new "missions" of the humanities in that context.

Keywords: university, humanities, technosphere, cybernetic difference, turn, artificial life 